colostrum, and were then kept for 3 weeks on the standard diet. Of the six calves deprived of colostrum five died. All the other calves survived.

3. The survivors scoured severely, and gained little weight during the experimental period.

4. Heating to $63^{\circ}$ for $30 \mathrm{~min}$. did not impair the protective value of the non-fatty fraction of colostrum.

The work here reported was done under a special grant from the Agricultural Research Council. It gives us much pleasure to thank farmers in the neighbourhood who willingly supplied calves for these experiments. We are indebted to Messrs Marcom Ltd. for supplying the special non-vitaminized margarine and to Mr Barbour of the Scottish Milk Powder Company for his help with supplies of dried skim milk. We wish to thank Miss E. Fawcus for valuable assistance with the experimental animals.

\title{
REFFRENCES
}

Aschaffenburg, R. (1949). Brit. Y. Nutrit. 3, 200.

Aschaffenburg, R., Bartlett, S., Kon, S. K., Terry, P., Thompson, S. Y., Walker, D. M., Briggs, C., Cotchin, E. \& Lovell, R. (1949). Brit. F. Nutrit. 3, 187.

Esh, G. C., Sutton, T. S., Hibbs, J. W. \& Krauss, W. E. (1948). Y. Dairy Sci. 31, 46 r.

Horrall, B. E. (1935). Bull. Ind. agric. Exp. Sta. no. 40 I.

\section{The Nutritive Value of Colostrum for the Calf}

\section{Changes in the Serum Protein of the Newborn Calf following the Ingestion of Small Quantities of the Non-fatty Fraction}

\author{
By R. ASCHAFFENBURG \\ National Institute for Research in Dairying, University of Reading
}

(Received 4 March 1949)

The serum of the newborn calf contains little or no euglobulin and pseudoglobulin I (Howe, $192 \mathrm{I} b$ ). A marked increase in these protein fractions results from the ingestion of colostrum. Similarly, more recent studies, particularly by E. L. Smith (for a summary see Smith, 1948), have demonstrated the absence from the serum of the newborn calf of electrophoretically slow-moving globulins and their appearance following the intake of colostrum. These globulins are identical with the 'immune lactoglobulins' present in colostrum. The properties of these fractions differ slightly but significantly from those of the $\gamma$-and $T$-components found in the serum of the adult bovine (Smith, 1948). With calves receiving large amounts of colostrum the appearance of the 'immune lactoglobulins' in the blood stream can be demonstrated with ease, but it was 
not known whether the small quantities of the non-fatty fraction of colostrum given in the main experiment of Aschaffenburg, Bartlett, Kon, Walker, Briggs, Cotchin \& Lovell (1949) would cause detectable changes in the serum proteins of the calves.

\section{METHODS}

\section{Sampling of blond}

Blood samples were obtained before the first feed and on the $4^{\text {th }}$ day of life from every calf used in the main experiment of Aschaffenburg et al. (1949), with the exception of a few animals at the beginning of the experiment. The choice of the $4^{\text {th }}$ day for the second sampling was dictated by reasons unconnected with this study. The delay was of little importance, as the rapid transfer of colostral proteins into the blood stream was found to be followed by a period of days during which the protein composition of the serum remained almost constant.

\section{Nitrogen partition in blood serum}

Total nitrogen and euglobulin nitrogen were determined by Kjeldahl analyses. The euglobulin was precipitated from $2 \mathrm{ml}$. of serum by the addition of $20 \mathrm{ml}$. of saturated sodium chloride solution followed by saturation with solid sodium chloride at room temperature. This procedure was preferred to the tedious precipitation with sodium sulphate at $37^{\circ}$. Howe (I92 I $a$ ) showed that the results obtained with these two methods of salting-out are almost identical.

\section{Globulin-turbidity test for blood serum}

Nitrogen determinations, even as outlined above, are time-consuming, and a simpler and quicker test for the presence of 'immune lactoglobulins' was developed.

\section{General}

Kunkel (I947) described a turbidimetric method for the detection and estimation of pathological increases in the $\boldsymbol{\gamma}$-globulin level of human serum, such as occur in certain diseases of the liver. The method consists in the measurement of the degree of turbidity developed when highly dilute metal-salt solutions, e.g. of copper sulphate or zinc sulphate, are allowed to react with serum. According to Kunkel, this reaction is specific for $\gamma$-globulin. As the 'immune lactoglobulins' are similar to, though not identical with, $\gamma$-globulin, the possible application of a test based on Kunkel's principle to calf serum was investigated. It was found that an approximately tenfold increase in the concentration of metal salt led to conditions under which no turbidity occurred with the serum of calves deprived of colostral proteins, whereas turbidities of an intensity reflecting the amount of proteins ingested developed after the calves had been given colostrum or its non-fatty fraction.

\section{Method}

Serum (0.1 $\mathrm{ml}$.) is washed out from a blood pipette into I $\mathrm{ml}$. of neutral distilled water (a) contained in a test-tube. Five $\mathrm{ml}$. of a solution of $250 \mathrm{mg}$. of $\mathrm{ZnSO}_{4} \cdot 7 \mathrm{H}_{2} \mathrm{O} / \mathrm{l}$. (b) are run in, and the contents of the tube are well mixed. The tube is left for $\mathrm{I}$ hr. (c), 
and the degree of turbidity is then determined in a photoelectric absorptiometer $(d)$ or other suitable instrument.

Notes. (a) It is unnecessary to buffer the system if care is taken that the distilled water used in the test and in making up the zinc-sulphate solution is neutral. If necessary, the $\mathrm{pH}$ may be adjusted by the addition of dilute acid or alkali to the water.

(b) Solutions of zinc sulphate rather than of copper sulphate were chosen, as they remain clear and stable for longer periods.

(c) 'The turbidities develop rapidly at first, and then at a decreasing rate. The reaction is not quite complete after $\mathrm{I}$ hr., but this period was arbitrarily chosen as convenient and satisfactory for comparative purposes.

(d) The turbidities were determined in the $2 \mathrm{~cm}$. cell of a Miller photoelectric absorptiometer (Morris, 1944), using the Ilford red filter no. 608. A reagent blank (no serum) was used to set the instrument to full-scale deflexion, and the turbidity readings were recorded as log-scale divisions, one division being equal to an extinction of 0.002 .

\section{General}

RESULTS

The results of the nitrogen determinations and of the turbidity tests are given in Table I which also includes some data for calves that had received large amounts of colostrum by suckling their dams.

\section{Total nitrogen}

There was an increase in the total nitrogen of the serum of the four calves that had been given $400 \mathrm{ml}$. of the non-fatty fraction, whereas no consistent changes resulted from the other treatments.

\section{Euglobulin nitrogen}

According to Howe (1921 $b$ ), the serum of the newborn calf does not contain euglobulin. Contrary to this statement, measurable amounts of euglobulin (mean: $33 \mathrm{mg}$./ $100 \mathrm{ml}$.) were, with the one exception of calf no. 18 , found in every serum obtained from newborn calves. With the calves that received no colostrum, a reduction in serum euglobulin was observed on the $4^{\text {th }}$ day when the calves were usually moribund. Where 80,200 , or $400 \mathrm{ml}$. of the non-fatty fraction were given, the changes in the euglobulin level were not consistent. Euglobulin nitrogen determinations were, therefore, not a valuable criterion in deciding whether or not a newborn calf had received small quantities of colostral proteins.

\section{Globulin-turbidity test}

'The simple turbidity reaction proved more sensitive: a clear-cut positive result was obtained with the serums taken on the $4^{\text {th }}$ day from all calves that had been given 200 or $400 \mathrm{ml}$. of the non-fatty fraction; $80 \mathrm{ml}$. was not sufficient to cause noticeable turbidity. Pl. I shows typical results for calves in one block given different quantities of the nonfatty fraction. The result for a calf that had suckled its dam is also shown. As the 
焉

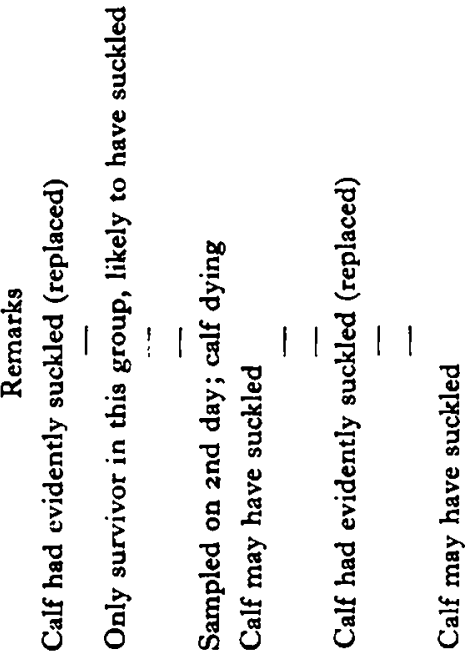

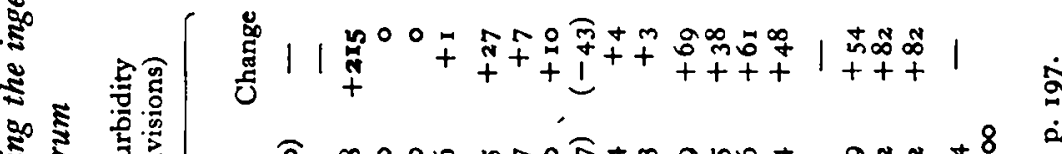
Nmoomgoo

\&

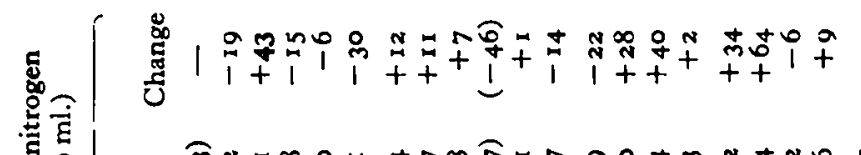

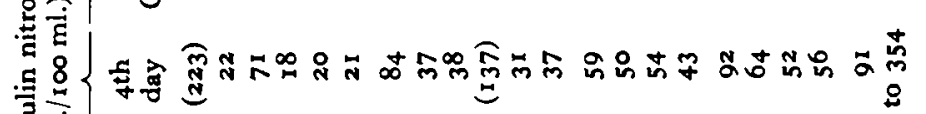

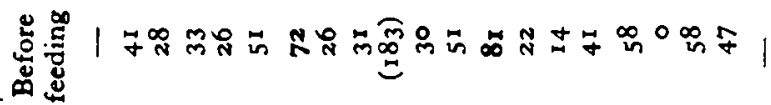

है :
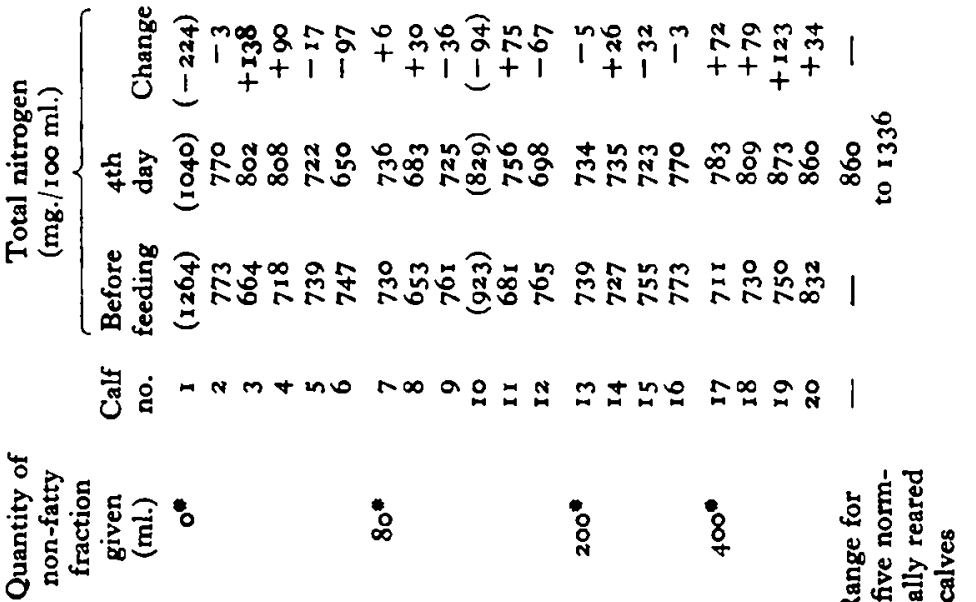

:

8 
turbidity test gave positive results with the serum of calves that had received relatively small quantities of colostral proteins, it has since been used to good purpose in eliminating from experiments newborn calves that had probably suckled their dams before being collected from the farms.

\section{Special observations}

(I) Data have been included in Table I for two calves (nos. I and ro) that had evidently received colostrum before they were collected.

(2) With two other calves (nos. 7 and 13 ), the initial strongly positive turbidity tests, supported by unusually high euglobulin nitrogen values, also suggest that these animals had managed to suckle.

(3) Quite normal results were obtained for the initial sample from the only survivor of the group of calves deprived of colostrum (no. 3), but marked increases in total and euglobulin nitrogen and in globulin turbidity were found with the $4^{\text {th }}$ day's sample. This suggests that the calf had, in fact, obtained colostrum. It can only be assumed that it had suckled such a short time before the first blood sample was taken, that no effective transfer of colostral proteins into the blood stream had yet occurred.

\section{SUMMARY}

I. When newborn Shorthorn bull calves received an initial allowance of the nonfatty fraction of colostrum (Aschaffenburg et al. 1949) not exceeding $400 \mathrm{ml}$., the bloodserum euglobulin did not increase consistently.

2. A simple turbidity test for serum with $c .0 .7 \mathrm{~mm}$-zinc-sulphate solution was developed. It proved sensitive to the transfer of 'immune lactoglobulins' from as little as $200 \mathrm{ml}$. of the non-fatty fraction of colostrum.

The work here reported was done under a special grant from the Agricultural Research Council.

\section{REFERENCES}

Aschaffenburg, R., Bartlett, S., Kon, S. K., Walker, D. M., Briggs, C., Cotchin, E. \& Lovell, R. (1949). Brit. F. Nutrit. 3, 196.

Howe, P. E. (1921 a). \%. biol. Chem. 49, Iog.

Howe, P. E. (1921 b). Y. biol. Chem. 49, Ir 5 .

Kunkel, H. G. (1947). Proc. Soc. exp. Biol., N.Y., 66, $2 \times 7$.

Morris, C. J. O. R. (1944). Brit. med. J. ii, 81.

Smith, E. L. (1948). F. Dairy Sci. 31, I27.

\section{EXPLANATION OF PLATE}

Pl. I. Typical results with the serum of calves that had been given different quantities of the non-fatty fraction of colostrum, and of a calf that had suckled its dam. $a=$ serum obtained before the first feed; $b=$ serum obtained on the $4^{\text {th }}$ day of life. 


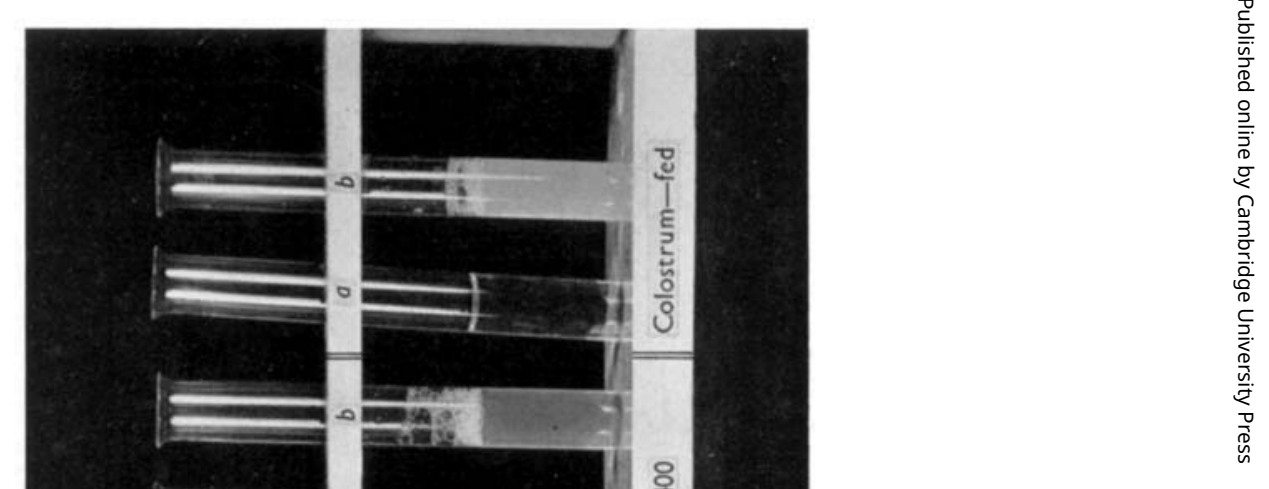

